\title{
Influence of an Intervention on the Motor Coordination of Children from 5-6 Years
}

\section{Influência de uma Intervenção sobre a Coordenação Motora de Crianças de 5-6 Anos}

\author{
Giovanna Sayuri Garbelini Ota*a; Geovane Silva Ramirez; ${ }^{\mathrm{a}}$ Hugo Cavalcante Vasques ${ }^{\mathrm{a}}$; Ademir de Marco ${ }^{\mathrm{a}}$
}

${ }^{a}$ State University of Campinas, Stricto Sensu Graduate Program in Physical Education, SP, Brazil.

*E-mail: g.giovannas@hotmail.com

Recebido em: 11/04/2019; Aprovado em: 18/06/2019

\begin{abstract}
In Infant Education the presence of the Physical Education teacher is not legitimized by law yet, however the literature evidences how the motor experiences are important during childhood. The varied interactions and deprivation of experiences have the potential to influence the child's development. Thus, the objective of the study was to determine the effects of a pedagogical intervention of Physical Education, on the motor coordination of children from 5-6 years, in a specific elementary school. The participants were two groups: the experimental group $(\mathrm{n}=10)$ and the control group $(n=25)$. The experimental group performed ten sessions of ludic activities, motor for 60 minutes, once a week, in space destined for body movement. At the beginning and end of the intervention all participants were evaluated by the Körperkoordination Test für Kinder (KTK). The results showed that the experimental group presented significant statistical improvements in the motor coordination when compared to the control group. Thus, the inclusion of the Physical Education teacher in the first stage of Basic Education becomes important, since it can contribute with the offer of diversified motor experiences and the development of young children.
\end{abstract}

Keywords: Motor Activity. Physical Education and Training. Child Development.

\section{Resumo}

Na Educação Infantil a presença do professor de Educação Física ainda não é legitimada por lei; porém, a literatura evidência como as vivências motoras são importantes na infância. As variadas interações e as privações de experiências apresentam potencial para influenciar o desenvolvimento da criança. Neste sentido, o objetivo do estudo foi determinar os efeitos de uma intervenção pedagógica da Educação Física sobre a coordenação motora de crianças de 5-6 anos de uma escola especifica de Educação Infantil. Os participantes constituíram dois grupos: grupo experimental $(n=10)$ e grupo controle $(n=25)$. O grupo experimental realizou dez sessões de atividades motoras lúdicas, durante 60 minutos, uma vez por semana, em espaço destinado a movimentação corporal. No início e término da intervenção todos os participantes foram avaliados pelo Körperkoordination Test für Kinder (KTK). Os resultados demonstraram que o grupo experimental apresentou avanços significativos estatisticamente na coordenação motora, quando comparado ao grupo controle. Assim, a inclusão do professor de Educação Física, na primeira etapa da Educação Básica se faz importante, pois pode contribuir com o oferecimento de experiências motoras diversificadas e com o desenvolvimento das crianças pequenas.

Palavras-chave: Atividade Motora. Educação Física Treinamento. Desenvolvimento Infantil.

\section{Introduction}

The first childhood is full of changes related to the child's development. In this stage of life, movement is understood as a propeller that contributes to the elaboration and organization in the motor, intellectual, affective and social aspects of the child. The debate on the importance of the movement in education has been the target of researchers in the area ${ }^{1-3}$. And, in particular, Physical Education with its particularities and closeness with the body in motion may contribute significantly to the child's development.

Although the physical education is compulsory curricular component of Early Childhood Education, is not guaranteed by law the presence of Physical Education teacher in this context. Thus, studies reveal the need of physical education teacher to conquer space in the routine of institutions of Early Childhood Education as a practice of pedagogical value ${ }^{4}$. Proposals and interventions demonstrate the potential of the Physical Education and its possible contributions to the children's integral development in this stage of Basic Education.

From this perspective, and in partnership with pedagogues and Physical Education teachers, the Study Group of Physical Education in Child Development (GEEFIDI) in cooperation with institutions of Early Childhood Education, developed and implanted rooms especially aimed at children's games. These spaces were named "Cri-cri room: Space for the Child Create" and aim to provide secure and encouraging environments for the children move. However, it is important to emphasize that the installation of these spaces do not have the objective of supplying any other existing or possible to exist in relation to the infrastructure of any institution of Early Childhood Education, but rather constitute one more option for the pedagogical planning in this context. 
In the continuation of this project it is aimed to investigate if the implementation of a pedagogical planning of motor activities of Physical Education in a space intended for bodily movement contributes to the child's development, in this case in relation to the motor coordination. The study aims to encourage the structuring of appropriate and stimulating environments to the actions and the systematized experiences of Physical Education in Early Childhood Education.

In this context the Physical Education teacher must participate in the planning of interdisciplinary pedagogical way, to contribute significantly to the aspects that involve the body movement.

\section{Material and Methods}

The study was analyzed and approved by the Ethics in Research Committee of the School of Medical Sciences of UNICAMP, with Legal Opinion number 937.801.

To participate in this study, the classes were selected by convenience, in accordance with the acceptance of pedagogues to participate in the research and the compatibility of timetables for the achievements of the interventions and assessments. The experimental group $(n=10)$ was conducted with children of an institution (Institution A) and the control group ( $\mathrm{n}=26)$ with the children of another institution (Institution B), all aged between five and six years. It is reiterated that the control group was selected in another institution, due to the fact that all children who attended the institution, even those who had not participated in the research, went to the Cri Cri room .

All these children were authorized by the parents or guardians for the realization of research with the completion of Free and Informed Consent Form.

\subsection{Instrument for data collection}

For data collection, the strategy of evaluation of motor development was based on Körperkoordination Test für Kinder - KTK, composed by four tasks, with individual reliability between 0.65 and 0.87 , and total reliability of $0.90^{5}$.

The performance in each task results in a score called Quotient Engine. The quotient Engine 1 (QM1) refers to the task balance beam, the quotient Engine 2 (QM2) the task of Monopedal jump, the quotient Engine 3 (QM3) the task side jump and the quotient Engine 4 (QM4) to the platforms transfer. The sum of the four quotient engines, results in Total Motor Quotient (QM) - Table 1.

Table 1 - Classification of the Body Coordination Test - KTK

\begin{tabular}{|c|c|c|c|}
\hline QM & Classification & $\begin{array}{c}\text { Standard } \\
\text { Deviation }\end{array}$ & $\mathbf{\%}$ \\
\hline $131-145$ & High Coordination & +3 & $99-100$ \\
\hline $116-130$ & Good coordination & +2 & $85-98$ \\
\hline $86-115$ & Normal Coordination & +1 & $17-84$ \\
\hline $71-85$ & Disturbances in Coordination & -2 & $3-16$ \\
\hline $56-70$ & $\begin{array}{c}\text { Insufficiency in the } \\
\text { Coordination }\end{array}$ & -3 & $0-2$ \\
\hline
\end{tabular}

Source: Research Data.
Each task has a specific goal in the context of the body coordination. The task balance beam aims to verify the stability of balance in backwards travel. In the task of the monopedal jump, it is investigated the coordination of lower limbs, as well as their dynamic energy and strength. The third task, side jump, characterizes the speed in alternating jumps. In the last task, platform transfer, it is observed the laterality and the spatial-temporal structure of the child ${ }^{5}$.

\subsection{Study design}

The study was structured in the following steps: motor assessment, planning, implementation of the pedagogical motor reassessment and, finally, the data analysis.

Initially, for two weeks the first motor assessment was performed in all participants. Then, the pedagogical planning composed of 10 sessions was performed, during 15 weeks with the experimental group in the Cri Cri room. In sequence, with a duration of two weeks, the post-test was held in both groups.

The focus of the pedagogical planning was to provide bodily experiences through games, and thus, promote new patterns of movements and refine the existing ones, aiming to contribute to the children's integral development, since in addition to the motor aspect, the children had coexistence in group and activities that demanded mutual cooperation. In addition, the bodily experiences explored the space, the materials and the possibilities to move around in the Cri Cri Room.

\subsection{Statistical analysis}

For the data statistical analysis, the Shapiro-Wilk test was initially used to verify the behavior of normal distribution. Then, before the normality of the data distribution, the t-test for paired samples was used, in the case of comparison between the results of the test and retest. For comparison of independent samples, the t-test was used for independent samples. The mean and standard deviation were characterized to analyze the variables collected. Significance level was set at $\mathrm{p}<0.05$.

\section{Results and Discussion}

It is worth noting that in spite of the mean age of the Control Group being higher than that of the experimental group, the results indicated the same prerequisite in relation to the coordination of both groups.

After 15 weeks of interventions, it was possible to observe that the task of Monopedal Jump and the side Jump presented significantly higher average scores; however, the standard deviation values also increased significantly, making the sample less homogeneous at the time of the second evaluation. Although the tasks of balance beam and Platforms Transfer have not presented significant differences between both evaluations, one can consider the trend of improvement 
of the KTK performance, because in all the tasks the absolute scores in the post-test are higher than in the pre-test in the experimental group (Table 2).

Table 2 - Descriptive statistics of the KTK test scores in the experimental group.

\begin{tabular}{|l|c|c|c|c|c|}
\hline \multirow{2}{*}{ Variable } & \multicolumn{2}{|c|}{ Average } & \multicolumn{2}{c|}{$\begin{array}{c}\text { Standard } \\
\text { Deviation }\end{array}$} & \multirow{2}{*}{ p-value } \\
\cline { 2 - 6 } & Pre & Post & Pre & Post & \\
\hline $\begin{array}{l}\text { Balance beam } \\
\text { (QM1) }\end{array}$ & 75.6 & 82.38 & 6.92 & 7.58 & 0.05 \\
\hline $\begin{array}{l}\text { Monopedal Jump } \\
\text { (QM2) }\end{array}$ & 85.1 & 100.25 & 11.56 & 21.95 & $0.007 *$ \\
\hline $\begin{array}{l}\text { Side Jump } \\
\text { (QM3) }\end{array}$ & 93.3 & 98.63 & 13.20 & 18.46 & $0.03 *$ \\
\hline $\begin{array}{l}\text { Platforms Transfer } \\
\text { (QM4) }\end{array}$ & 91.2 & 96 & 13.69 & 12.86 & 0.15 \\
\hline $\begin{array}{l}\text { Total Motor } \\
\text { quotient (QMT) }\end{array}$ & 82.1 & 92.5 & 11.17 & 16.72 & $0.002 *$ \\
\hline
\end{tabular}

* Significance level $\mathrm{p}<0.05$

Source: Research Data.

The experimental group showed a statistically significant difference $(p=0.002)$ in the Total Quotient Engine after the intervention program. Furthermore, the general classification of the group, according to "KTK", amounted to a level, went from "disturbances in motor coordination" to "Normal Coordination".

It is observed that all of the post-test scores were higher than those of the pre-test, and the increase in the standard deviation despite not having exceeded 10 points, might be justified by the absence of two students who participated in only $40 \%$ of the sessions, and did not obtain gains in the test, thus resulting in a discrepancy in the scores. Regarding the rest of the participants, all performed at least $60 \%$ of the intervention program.

The control group showed statistically significant gains only in the task of lateral jump and remained homogeneous when compared to the pre-test (Table 3). In the task Platforms Transfers, there was also statistically significant difference, this difference, negative, because the average has declined in the post-test. The remaining tasks remained with the same performance.

Table 3 - Descriptive statistics of the KTK test scores in the control group.

\begin{tabular}{|l|c|c|c|c|c|}
\hline \multirow{2}{*}{$\begin{array}{l}\text { Engine quotient } \\
\text { of the Task }\end{array}$} & \multicolumn{2}{|c|}{ Average } & \multicolumn{2}{c|}{$\begin{array}{c}\text { Standard } \\
\text { Deviation }\end{array}$} & \multirow{2}{*}{ P-value } \\
\cline { 2 - 5 } & Pre & Post & Pre & Post & \\
\hline $\begin{array}{l}\text { Balance beam } \\
\text { (QM1) }\end{array}$ & 82.24 & 85.86 & 13.88 & 13.92 & 0.08 \\
\hline $\begin{array}{l}\text { Monopedal Jump } \\
\text { (QM2) }\end{array}$ & 93.43 & 100.00 & 16.94 & 16.51 & $0.008^{*}$ \\
\hline $\begin{array}{l}\text { Side Jump } \\
\text { (QM3) }\end{array}$ & 96.00 & 95.38 & 11.77 & 12.35 & 0.38 \\
\hline $\begin{array}{l}\text { Platforms Transfer } \\
\text { (QM4) }\end{array}$ & 83.33 & 75.62 & 11.78 & 14.06 & $0.01^{*}$ \\
\hline $\begin{array}{l}\text { Total Motor } \\
\text { quotient (QMT) }\end{array}$ & 85.4 & 85.9 & 14.12 & 12.74 & 0.45 \\
\hline
\end{tabular}

* Significance level $\mathrm{p}<0.05$

Source: Research Data.
The control group comprised 25 children, showed no statistically significant difference $(p<0.05)$ in the scores of the Total Motor quotient during the 15 weeks of the study (Table 3). Furthermore, the general classification of the group, according to the "KTK", remained at the same level.

In Table 3 the comparisons among the scores presented by the Experimental and Control Groups are described. In all the variables, specifically in the pre-test, no significant differences were found. This indicates the same precondition for both groups.

Table 4 - Means of the Experimental and Control Groups in the pre-test and post-test.

\begin{tabular}{|c|c|c|c|}
\hline Variable & $\begin{array}{c}\text { Average - } \\
\text { Experimental } \\
\text { Group }\end{array}$ & $\begin{array}{c}\text { Average } \\
- \text { Control } \\
\text { Group }\end{array}$ & p-value \\
\hline Pre-test & 75.6 & 82.24 & 0.10 \\
\hline MQ1 & 85.1 & 93.43 & 0.21 \\
\hline MQ2 & 93.3 & 96.00 & 0.47 \\
\hline MQ3 & 91.2 & 83.33 & 0.16 \\
\hline MQ4 & 82.1 & 85.43 & 0.42 \\
\hline Sum Score & 82.38 & 85.86 & 0.39 \\
\hline Post-test & 100.25 & 100 & 0.97 \\
\hline MQ1 & 98.63 & 95.38 & 0.65 \\
\hline MQ2 & 96 & 75.62 & $0.002 *$ \\
\hline MQ3 & 92.5 & 85.9 & 0.31 \\
\hline MQ4 & &
\end{tabular}

* Significance level $\mathrm{p}<0.05$

Source: Research Data.

In the case of post-test, despite having been found significant differences only in the task platforms transfer, the absolute scores in the experimental group were higher than in the control group, except in the task Balance Beam (Table 4). However, it should be considered that during the 15 weeks there was approximation to the value of the control group, when compared in the pre-test of this task.

The findings indicate that the program of pedagogical intervention positively influenced the levels of the children's motor coordination in the Experimental Group.

However, it was also observed that there was in motor coordination in the control group, inferring possible progress in the child's natural development, on account of intrinsic factors and maturation. Corroborating Papalia ${ }^{6}$ who indicates the main factors that influence the development in general: heredity (genetic characteristics transmitted from biological parents), the environment (all external influences to the child) and maturation (unfolding of a natural sequence genetically influenced physical changes and patterns of behavior).

Another important point, and that although the KTK in its theoretical foundation does not explore, is on the child's psychological status at the time of the test completion. The psychological sphere, which the child is to the tests completion might, hypothetically, interfere in her performance at that moment. Despite the test not being possible to be performed under these circumstances, i.e., when it is realized malaise 
of the testing individual, the test is suspended. However, the child's subjective factors may not be perceived by the researcher. This is believed to be a factor inherent in any test, this being one of the criticisms for its use, therefore, the motivational factor may explain some of the data shown by the child.

Even through the application of tests, it is evident that there are qualitative aspects of intellectual and functional functions in the human body that remain inaccessible, and despite these restrictions, with a margin of error is very small, there is no denying the importance of data collected by means of the tests ${ }^{7}$.

At the same time that regression was identified in the Platforms transfer task (Table 3). As suggested by the literature $^{8}$ the course of development of each component of the motricity may present characteristics of non-linearity, characterizing the process of motor development as dynamic. Thus, this task showed no linearity, but it a feature of this process, for this age range.

However, the importance of motor interventions is explored in the literature ${ }^{3,5,9}$ although the number of studies in early childhood education is lower, the contributions to the motor development are evident in all stages of education and training.

Specifically, in the children education, there is a need to work together with professionals from different areas, since it is characterized as level summarily interdisciplinary. The joint action of professionals in conducting this study corroborates the authors ${ }^{1,2}$ being highlighted that the presence of teachers from different areas, in partnership in education and interacting with the children, constitutes a rich possibility of intervention and contribution to this level of Basic Education.

In this sense, in addition to the trend of improvement in motor coordination from the pedagogical planning, the study provided the children contact with different manifestations of movements suitable for small children. Just as Garanhani ${ }^{10}$ points out, who says that the bodily movement in addition to being a means for the physical-motor development, it is also loaded with meanings, expressions and understandings present in the sociocultural context. -

\section{Conclusion}

During the execution of the study some limitations were identified so that the results could be more defined. As the possibility of the duration of the intervention, the greater number of sessions would probably result in more consistent findings. However, this research showed one of the many possible contributions that the Physical Education teacher might insert into the context of Early Childhood Education. His or her knowledge about the body and to the development of the same, can contribute significantly in the institutions of Early Childhood Education, acting in the structuring of stimulating environments, proposing actions and experiences systematized suitable for this specific age. However, the intention is recorded regarding the need for more studies to be performed at this level of basic education, in order to be affirmed the performance and the contribution of the Physical Education teacher.

\section{Acknowledgments}

The authors thank Conselho Nacional de Pesquisa - CNPq for the financing of the same and the Coordenação de Aperfeiçoamento de Pessoal de Nível Superior - Capes.

\section{References}

1. De Marco A. Brincando e aprendendo com a educação física na educação infantil, In: Moreira WW, Marocolo Júnior M, Chaves AD, Carbinatto MV (Org.). Ciência do esporte: educação, desempenho e saúde. Uberaba: UFTM; 2012.

2. Garanhani MC, Nadolny LDF. A linguagem movimento na educação de bebês para a formação de professores. Educ Realidade 2015;40(4):1005-26. doi: 10.1590/2175623651737

3. Jung S, Seemann JLN, Nunes ACC, Souza J, Bastos SRS. A educação física na educação infantil: contribuições para o processo de desenvolvimento. Revista Uniplac 2018;6(1).

4. Silveira J. Reflexões sobre a presença da educação física na primeira etapa da educação básica. Motrivivência 2015;27(45):13-27. doi: 10.5007/2175-8042.2015v27n45p13

5. Gorla JI, Araújo PF, Rodrigues JL. Avaliação motora em educação física adaptada: teste KTK para deficientes mentais. São Paulo: Phorte; 2009.

6. Papalia, DE, Feldman RD. Desenvolvimento humano. Porto Alegre: Artmed; 2013

7. Gorla JI, Rodrigues JL, Brunieira CAV, Guarido EA. Testes de avaliação para pessoas com eficiência mental: identificando o KTK. Arq Ciênc Saúde UNIPAR 2000;4(2):121-8. doi: 10.25110/arqsaude.v4i2.2000.1016

8. Caetano MJD, Silveira CRA, Gobbi LTB. Desenvolvimento motor de pré-escolares no intervalo de 13 meses. Rev Bras Cineantropom Desempenho Hum 2005:7(2):5-13. doi: $10.5007 / \% 25 x$

9. Soejima CS, Bolsanello MA. Programa de intervenção e atenção precoce com bebês na educação infantil. Educar Rev 2012;43:65-79. doi: 10.1590/S0104-40602012000100006

10. Garanhani MC. A educação física na escolarização da pequena infância. Pensar Prática 2006;5:106-22. doi: 10.5216/rpp. v5i0.49 